\title{
Analysis Application Design Career Development Center in The STMIK Insan Pembangunan and (Case Study: Information Study Program)
}

\author{
Safrizal ${ }^{1}$, Gusti Nyoman Budiadyana ${ }^{2}$ \\ Jurusan Sistem Informasi, STMIK Insan Pembangunan \\ Jl. Raya Serang Km. 10 Bitung-Tangerang \\ e-mail:safrizal.st.mm@gmail.com, nyoman@csahome.com
}

To cite this document:

Safrizal, S., \& Budiadyana, G. (2019). Analysis and Application Design Career Development Center in The STMIK Insan Pembangunan (Case Study: Information Study Program). IAIC

Transactions on Sustainable Digital Innovation (ITSDI), 1(1), 66-77. Retrieved from

https://aptikom-journal.id/index.php/itsdi/article/view/20

\begin{abstract}
In order to facility data of ex-graduate maintaining and career information distribution to all of member of STMIK Insan Pembangunan especially Information System, information system is made to handle that. It is an application that named Career Development Center. In processing that aplication, the writer do examination by interview, observation and from books or literatures and then continue to model it with UML diagrams. Along with this system, it is hoped that recapitulaton of ex-graduate and career information spreading about job vacancy, tips and training/workshop can help user to maintain it.
\end{abstract}

Key Words : UML, Career, ex-graduate, STMIK Insan Pembangunan, Analisys

\section{Introduction}

Career is one thing that is significant for every individual because in the view of the community the higher the level of one's career, it is believed that the higher the quality and standard of living of that person. In this era of increasingly advanced globalization, everyone strives to achieve high career paths, one of which is through improving the quality of individual education.

STMIK Insan Development Bitung is one of the tertiary educational institutions in the Tangerang area that conducts lecture activities and consists of two majors namely information systems at the undergraduate (S1) level as well as rakuntance computing at the diploma level (D3). Graduates from this tertiary institution are expected to be able to obtain careers in accordance with their fields of expertise, interests and talents and in accordance with their current or current major. Aware of things

That, STMIK Insan Pembangunan Bitung seeks to help improve student careers by always providing information on vacancies that can help students to enter the workforce, but the information is still announced through a wall magazine. This certainly does not reach all students, especially alumni who also definitely need information without having to go to campus. In addition to the limited scope of information recipients, this institution also does not yet have 


\section{Aptikom Transactions on Sustainable Innovation (ATSI) Vol. 1 No. 1 October 2019}

a computerized system for tracking alumni to monitor and obtain information about the number and conditions of career alumni absorption in the world of work.

Therefore, special applications are needed to manage alumni data and delivery of information about careers in the form of vacancies, tips, training / training for students and alumni of STMIK Insan Pembangunan.

\section{Research Method}

The method used in the study follows the system development process with the Rapid Application Development (RAD) Model which is done with an object-oriented approach that has a very short time so that it is produced in the form of prototypes only. (Kendall, 2010). Before making the model, the data collection method was conducted through interviews, namely by asking directly to the Assistant Staff of the Chairperson (PUKET) 1 and the Chair of the Information Systems Department, Observation, namely conducting research or direct observation on the information delivery and alumni data collection procedures, and strengthened by the Literature Study of the theories, literature and journals related to research to strengthen the results of the analysis.

After obtaining a number of data, an object-oriented approach is modeled using UML diagram tools, namely Case Case Diagrams, Class Diagrams, Activity Diagrams, Sequence Diagrams, and finally the User Interface.

\section{DISCUSSION}

Career Development Center or known as the CDC is a system at the university that takes care of the career paths of students and graduates produced. The purpose of the CDC is to improve the quality of service for the integration of academic activities with the world of work, improve the quality of alumni and students to have integrity with the business world, increase cooperation activities with stakeholders (community and business world), help companies by providing a qualified, skilled and skilled workforce professionals in accordance with company needs, carry out recruitment of labor, know the position of graduates who have absorbed the workforce, prepare graduates in accordance with the competencies needed in the world of work.

The functions and activities carried out in the career development system in higher education are as Tracer Study (alumni tracking) and the Online Job Fair, to facilitate job seekers to find work in accordance with their talents, interests and skills, job fair exhibitions, campus recruitment, training campus, Promosi pusat karir, Internship and work Counseling,

The Application Development Center that will be discussed is an information management application related to career, in the form of vacancies, tips, training / training around careers and alumni data collection. In managing information about the career of STMIK Development Insiders have certain procedures but do not yet have a computerized system.

Next is a description of the activity diagram system that runs at STMIK Insan Pembangunan 


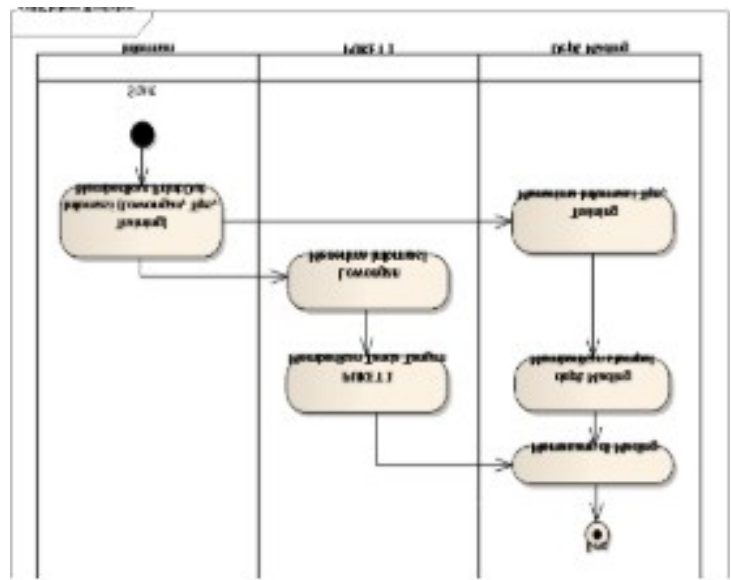

GAMBAR 1. Sistem Berjalan Pemasangan

Informasi Karir

\section{Caption:}

In the system activity diagram that runs starting from the informant who provides print out information (vacancies, tips, training), where the results of this print out will be given to PUKET 1 and the mading department provided that PUKET 1 will receive job information and the mading department will receive information tips and training, after PUKET 1 receives the vacancy information, the vacancy will be signed by PUKET 1 and then submitted to the bulletin department to be posted on campus. The bulletin board will give a new bulletin stamp and then post the information in bulletin boards

Activity Alumni Data Diagram

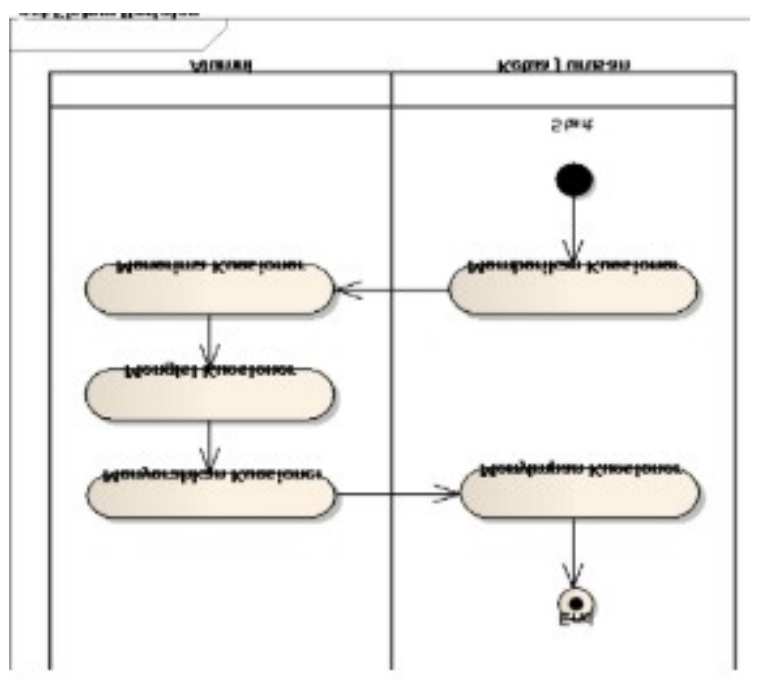

GAMBAR 2.Sistem Berjalan Pendataan

Alumni 


\section{Aptikom Transactions on Sustainable Innovation (ATSI)}

Vol. 1 No. 1 October 2019

Information :

The head of the department will give the questionnaire to the alumni at the time of thesis collection, the alumni will receive and fill out the questionnaire then return the questionnaire to the head of the department, and the results of the questionnaire will be stored by the head of the department.

conducted an analysis of the systems running on STMIK Development Persons found several problems, namely:

1. Submission of information on turning the bulletin board is still manually, namely through wall magazine.

2. Difficulties in knowing alumni absorption data in the data collection world are still done manually through the ertracer study questionnaire.

3. Difficulties in monitoring the alumni career status because the results of tracer studies have not been computerized.

\subsection{Formula/Algorithm [optional]}

analysis Resolution of problems

Based on the problems that occur in STMIK Development Persons, the authors propose an alternative problem solving in the form of making alumni data management information systems and information data about web-based careers with MySQL so that information can be disseminated more broadly and on time compared to conventional methods. This system will also produce reports on alumni that can be used by STMIK Development Personnel.

Discussion on System Analysis and Design proposed by researchers System Design Model in use case as follows:

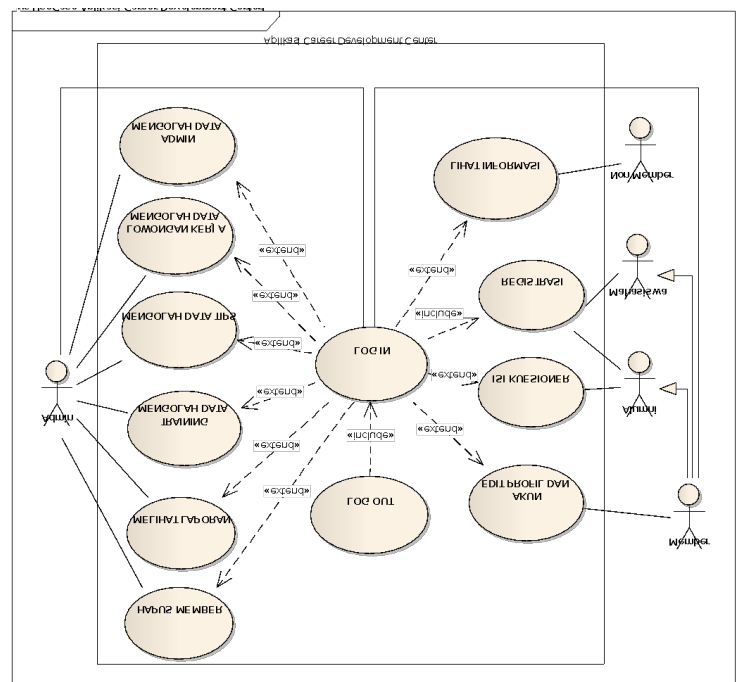

Figure 3.Use Case Diagram Career

Information : 


\section{Aptikom Transactions on Sustainable Innovation (ATSI)}

Vol. 1 No. 1 October 2019

The design of a system for delivering career and alumni information consists of several users, namely:

Member (has access rights), consisting of admin, students and alumni.

Non Member, general user who does not or does not have access rights.

The scenario explanation of the use case above is:

A. Actors must log into the system where this is to describe the activities of the admin and members who access the application completely and thoroughly.

B. Admin processes data to add new admins, deletes, changes profiles, admin username and password that have been registered, admin processes vacancies, namely admin's activities in adding, deleting and changing job vacancy information, Processing Data Tips namely to add, delete and modify information tips, Processing Training Data in this case to add, delete and change training information and View Reports from this system. And Delete member allows the admin to delete member membership.

C. Alumni and Students register as members and get login privileges.

D. Alumni will fill out a Questionnaire specifically for alumni who can fill in the tracer study questionnaire. so that later you can become a member

E. Members can edit their profile and account

F. Member and Non Member can see information about careers.

G. Actors can exit the system by logging out

Activity Diagram Usulan

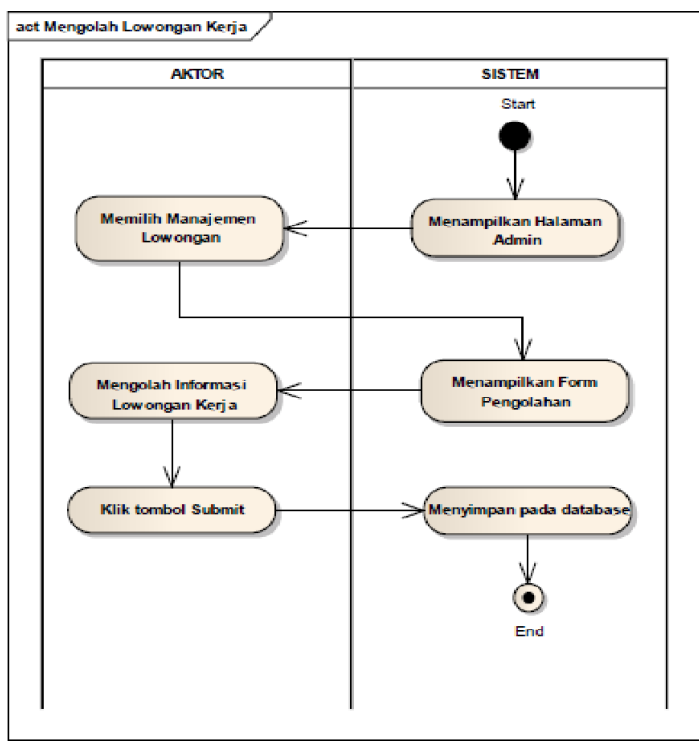

Figure 4.Class Diagram Career Development Center Application

Information : 
The system will display the admin page and the admin will select the vacancy management menu then process the vacancy and click the submit button then the system will save it to the database

\section{Activity Diagram Login kedalamsistem}

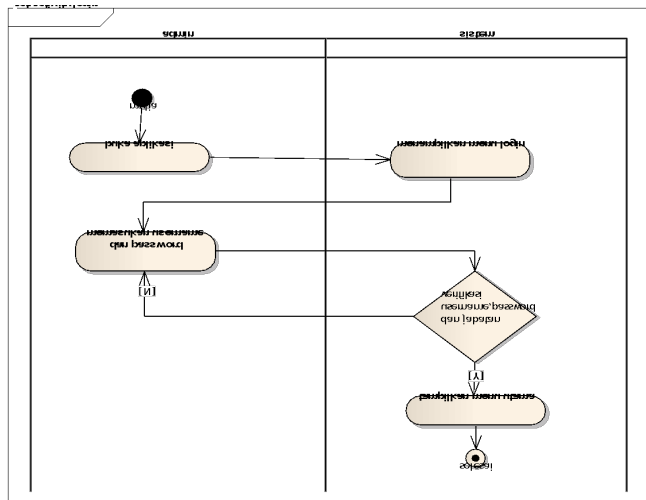

Figure 5.Activity Diagram Login

Information :

Admin starts the login process

Enter input usename and password

Usename and password validation inputted by the admin

If the data is correct it will enter the main menu, if not it will return to the input menu username and password

Admin login process is complete

Activity Diagram See Information

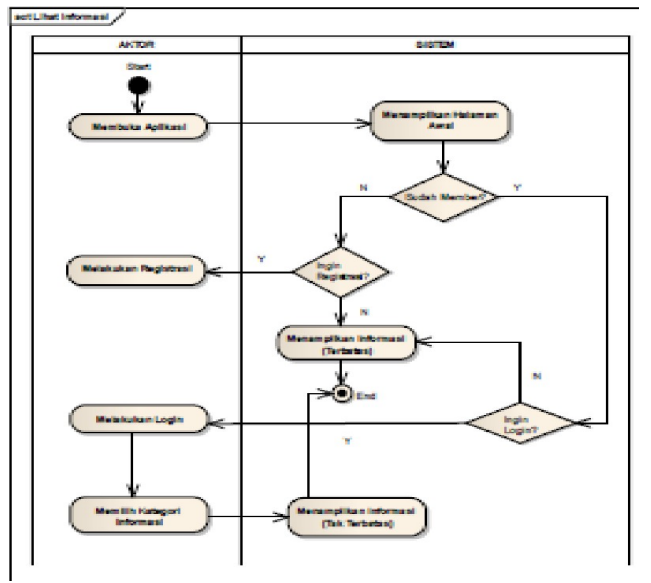

Figure 6.Activity Diagram LihatInformasi
A. Actor can open the application
B. The system will display the home page or home
C. Asking Valida who is a member or not a member
D. If so, it will verify to the login menu and enter the system
E. Select the desired information and the system will display the information desired by the actor


F. If not, it will be entered into the verification to submit as a member and register

\section{Sequence DiagramUsulan}

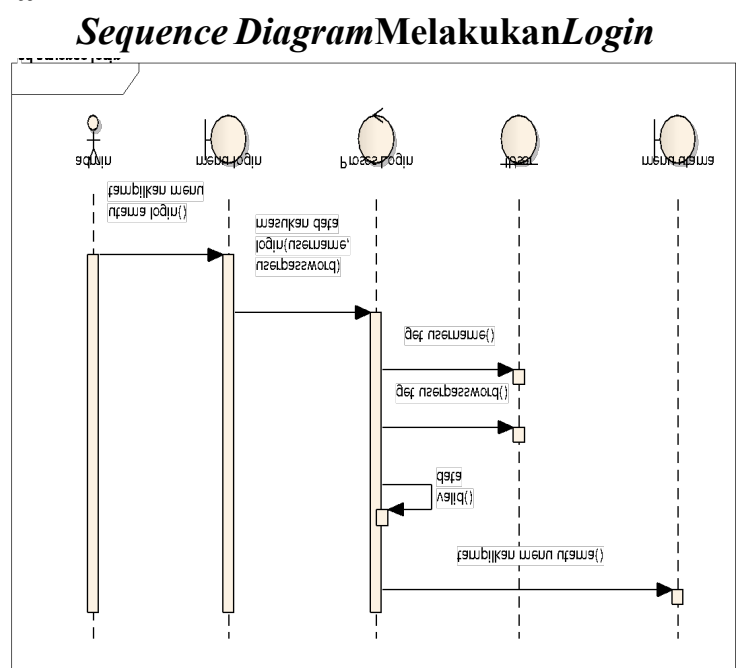

Figure 7. Sequence Diagram logged in

Information :

Display the login menu and enter your username and password into the login menu After entering the username and password that will be processed by the system, if successful the main menu will appear if it fails will display invalid data notification

\section{Sequence Diagram Mengelola Data User /Admin}

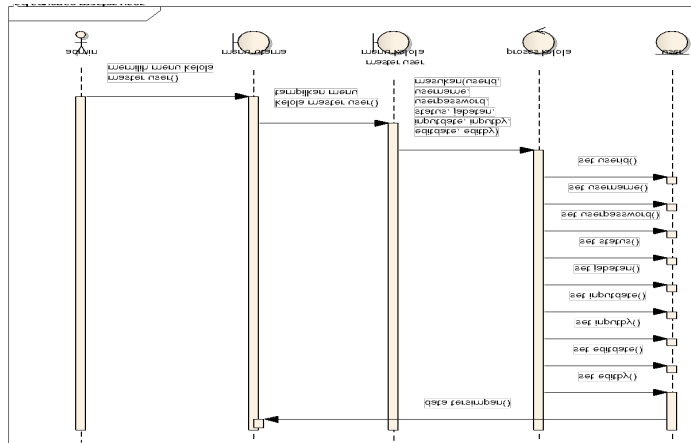

Figure 8. Equity Diagram manages User data

Information :

1. Select the master user menu and enter the fields that must be filled accordingly

2. After all fields are filled in, save them in the database

3. the fields are filled in according to the data stored if the data is wrong then a data notification will appear wrong

\subsection{Literature Review}

\section{Class Diagram Usulan}




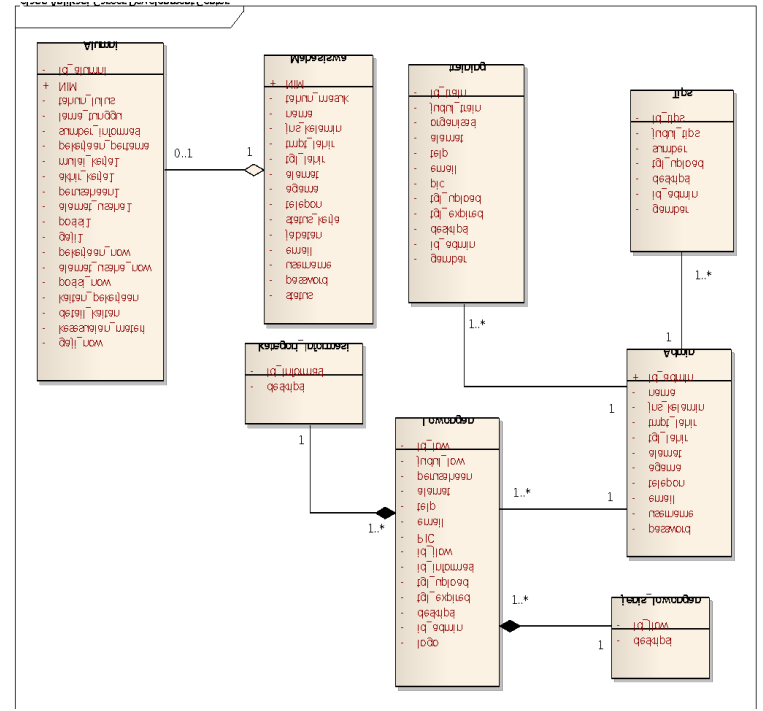

Figure 9.Class Diagram

Information :

Two (2) master tables, namely: master students and master alumni

Four (4) Transaction tables, namely: Vacancies, Training, tips and information

\section{Perancangan Design Form Tampilan Menu Utama}

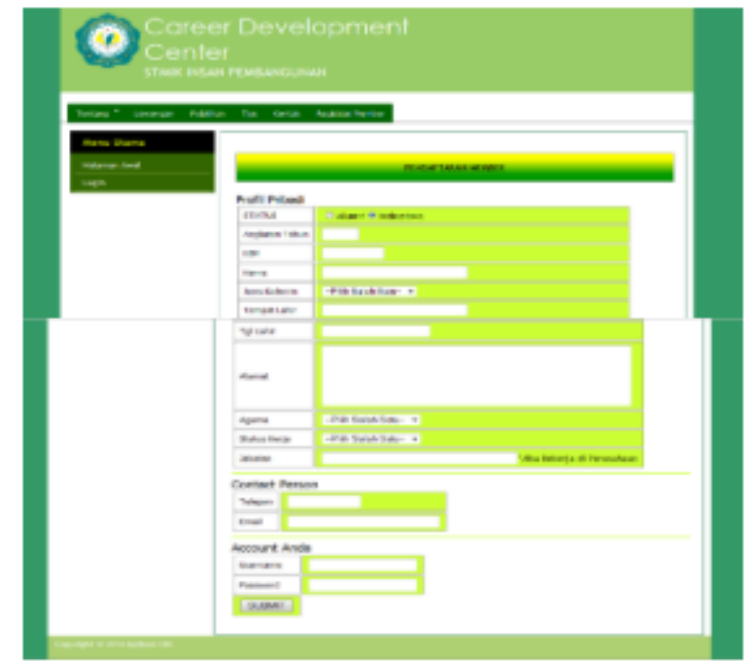

Figure 10. Display User Interface User Registration Information :

This member registration menu contains personal data to be filled out by students or alumni. This data will be the data that will be used in providing the information needed in accordance with the account provided. 
Aptikom Transactions on Sustainable Innovation (ATSI)

Vol. 1 No. 1 October 2019

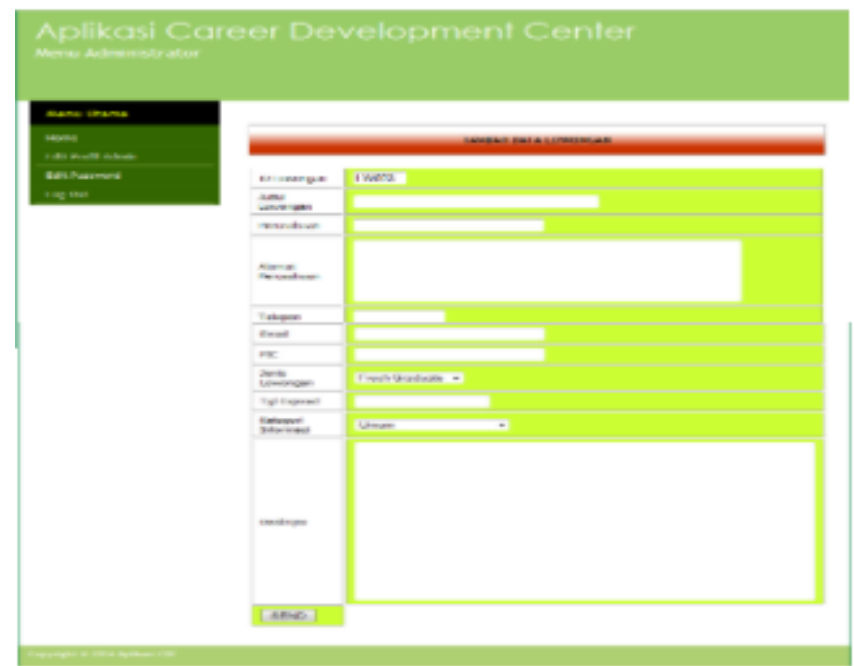

Figure 11. Display User Interface Add Job Data

Information :

Admin will add job data from companies that request jobs, this data will contain job title, company name, company address, telephone number and email address, as well as a special description for occupying the vacancy

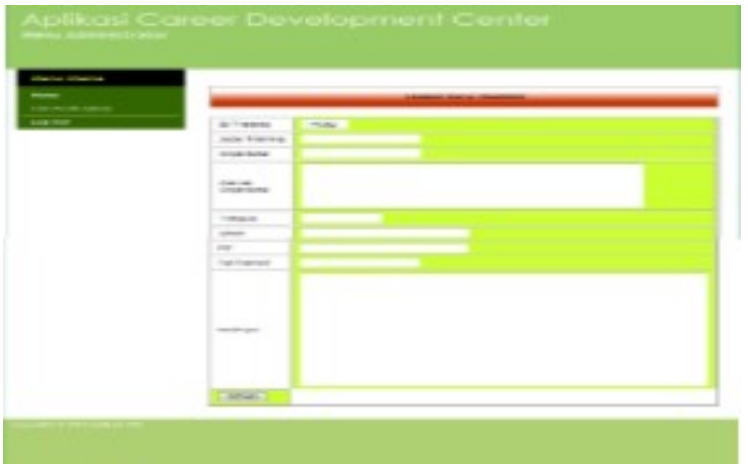

Fligure 12. Display User Interface Add Training Data

Information :

Admin will add training data, this data will contain the training title, organization, organization address, telephone number and e-mail address, as well as a special description for participating in the training. 
Aptikom Transactions on Sustainable Innovation (ATSI)

Vol. 1 No. 1 October 2019

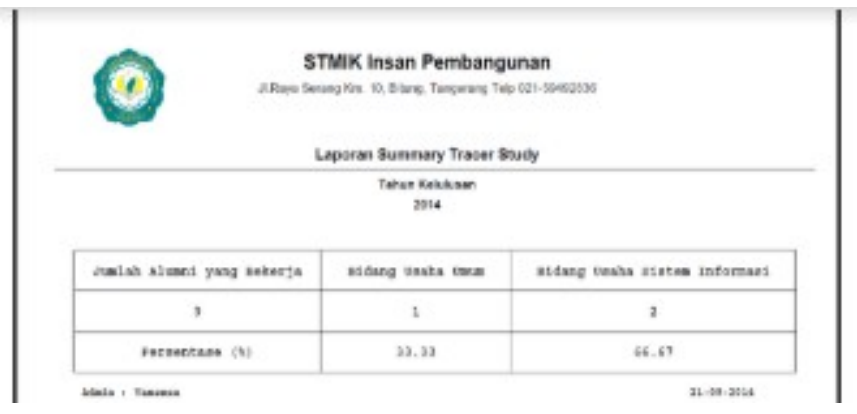

Figure 13. Display of Student Data Summary Report

Information :

This data contains a summary of student data reports from the apparatus of the number of students who are working, entrepreneurial and those who have not worked.

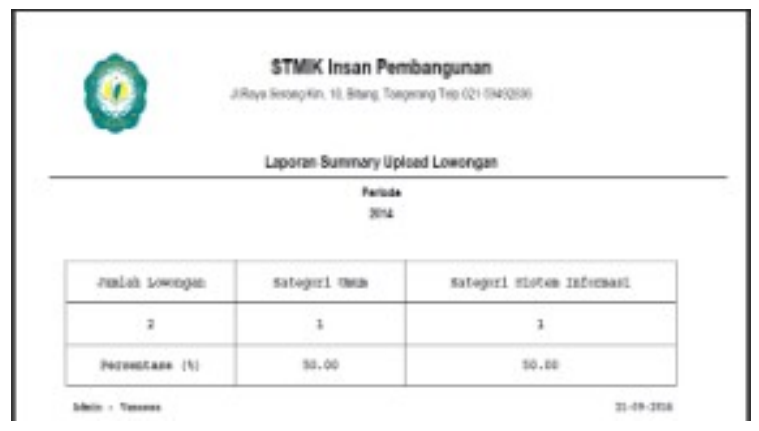

figure 14. Display Report Summary Upload Jobs

Information :

This data contains a summary report data Upload data vacancy number of existing vacancies, both in general category and in accordance with the information system majors 


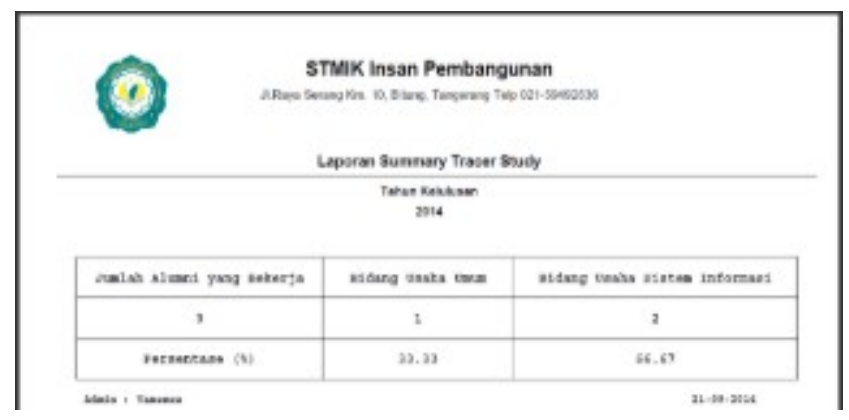

Figure 15. Display of Tracer Study Report Summary

Information :

This data contains summary tracer study report data in accordance with the year of graduation of students, this data also contains the number of alumni employed, business fields covering general and in accordance with information systems majors

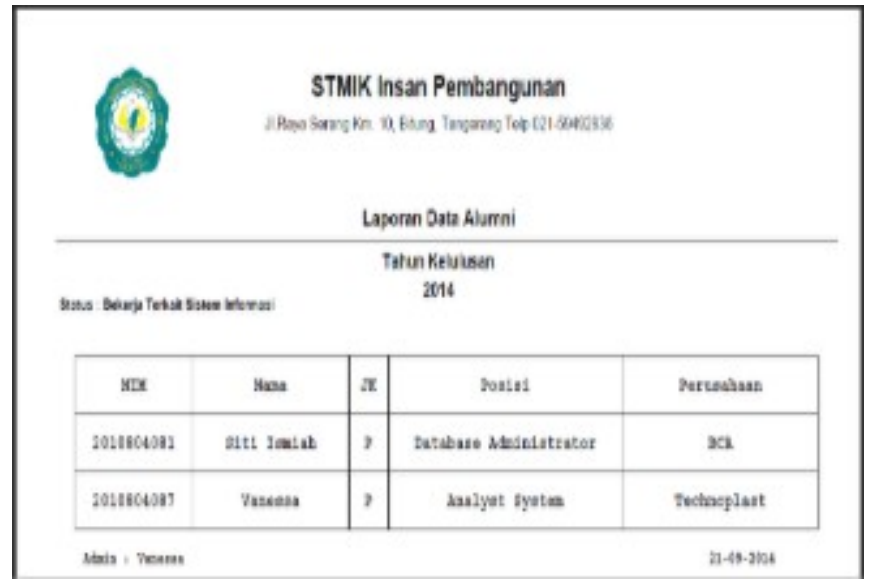

Figure 16. Display of Alumni Data Reports (Related to Tracer Study)

Information :

This data contains alumni data report data in accordance with the year of graduation of students, this data also contains the number of alumni employed, in accordance with the position or position held by the company that is now occupied.

\section{Conclusion}

Based on the results of the analysis and design of the Career Development Center application by the author, it can be concluded that: 


\section{Aptikom Transactions on Sustainable Innovation (ATSI)}

\section{Vol. 1 No. 1 October 2019}

1. The existence of the iCareer Development Center application can facilitate students

2. in accessing information about vacancies, tips and training without limited space and

3. time.

4. Through this application the campus can conduct supervision and verification of the dissemination of information about careers and their sources.

5. The Head of the Department or academic field can supervise the amount of alumni absorption in the workforce as well as the alumni career history.

Suggestions that can be given for the future development of this system include:

Developing applications to cover all departments at STMIK Development Persons

Make applications that can be accessed by gadgets or mobile phones.

Linking applications with social media to expand information dissemination.

Designing more dynamic and interactive web applications.

Designing applications that cover all aspects of the Career Development Center such as online job fairs, job fair exhibitions, campus recruitment, and online counseling.

\section{References}

[1] Hermawan, Jony. 2011. Perancangan Career Development Center UNDIP Berbasis Web. Skripsi Sarjana. Semarang : Universitas Diponegoro.

[2] Indrajani. (2011). Perancangan Basis Data dalam All in 1. Jakarta : Elex Media Komputindo

[3] Kendall, Kenneth \& Julie Kendall. Analisis dan Perancangan Sistem Terjemahan: Thamir Abdul Hafedh Al-Hamdany. (2010). Jakarta : Indeks

[4] Mulyanto, Agus. (2009). Sistem Informasi Konsep dan Aplikasi. Yogyakarta : Pustaka Pelajar [5] Sidik, Betha. (2012). Pemrograman Web dengan PHP Edisi Revisi. Bandung : Informatika

[6] Sirait, Samuel Marthin. (2013). Abstraksi Perancangan Aplikasi Career Development Center (CDC) STT-PLN Berbasis Android. Tersedia http://202.159.8.146/server/media.php?module=detailskripsi\&id=3796 (13 April 2014, $22.54 \mathrm{WIB})$

[7] Sutabri, Tata. (2012). Analisa Sistem Informasi. Yogyakarta : ANDI

[8] Sutanta, Edhy. (2012). Basis Data dalam Tinjauan Konseptual. Yogyakarta : ANDI

[9] Wahyumardi. 2010. Analisis dan Perancangan Sistem Informasi Lowongan Kerja UIN Karir (Studi Kasus Program Studi Sistem Informasi). Skripsi Sarjana. Jakarta : Universitas Islam Negeri (UIN) Syarif Hidayatullah.

[10] Widodo, Prabowo Pudjo dan Herlawati. (2011). Menggunakan UML. Bandung :Informatika

[11] Yasin, Verdi. (2012). Rekayasa Perangkat Lunak Berbasis Objek. Jakarta : Mitra Wacana Media 